\title{
Effect of exercise on lipid peroxidation in student soccer players
}

\author{
Desty Ervira Puspaningtyas ${ }^{1,2^{*}}$, Yuni Afriani ${ }^{1,2}$, Silvi Lailatul Mahfida ${ }^{1}$, Wara Kushartanti ${ }^{3}$ \\ and Arta Farmawati ${ }^{4}$ \\ ${ }^{1}$ Public Health Postgraduate Program, Faculty of Medicine, Universitas Gadjah Mada, \\ Yogyakarta, ${ }^{2}$ Nutrition Science Program, Faculty of Health Sciences, Universitas Respati \\ Yogyakarta, Yogyakarta, ${ }^{3}$ Faculty of Sport Science, Universitas Negeri Yogyakarta, \\ Yogyakarta, ${ }^{4}$ Department of Biochemistry, Faculty of Medicine, Universitas Gadjah \\ Mada, Yogyakarta
}

DOI: http://dx.doi.org/10.19106/JMedSci005001201811

\section{ABSTRACT}

Training is conducted to improve physiological functions that can support improvement of cardio-respiratory function ( $\mathrm{VO} 2 \mathrm{max}$ ). However, intensive training can lead to oxidative stress, which can contribute to health problems. The purpose of this study was to evaluate the effect of training on serum lipid peroxidation levels in student soccer players. The study was pre-experimental study with a one-shot case design conducted in April 2014. Twelve student soccer players from UGM who chosen by purposive sampling and met the inclusion and exclusion criteria were involved in the study. Each subject received training in the form of $\mathrm{VO} 2 \mathrm{max}$ measurements using the yo-yo intermittent recovery test. Plasma malondialdehyde (MDA) levels were measured using the thiobarbituric acid method $30 \mathrm{~min}$ after $\mathrm{VO} 2 \mathrm{max}$ measurement. Pearson correlation was used to analyze the correlation between $\mathrm{VO} 2 \mathrm{max}$ and plasma MDA levels. The mean age of subject was $19.25 \pm 1.06$ years old. Subjects had normal nutritional status (body mass index $20.99 \pm$ 1.65 ) with mean body weight of $58.13 \pm 3.76 \mathrm{~kg}$ and mean height of $166.2 \pm 3.40 \mathrm{~cm}$. The mean $V O 2 \mathrm{max}$ score was $49.56 \pm 0.61 \mathrm{~mL} / \mathrm{kg} / \mathrm{min}$. The mean plasma MDA level was $4.32 \pm 2.09 \mu \mathrm{mol} / \mathrm{L}$. There was no significant correlation between $V \mathrm{O} 2 \mathrm{max}$ and plasma MDA levels $(p=0.7717)$. In conclusion, training does not negatively impact oxidative stress conditions in student soccer players.

\section{ABSTRAK}

Latihan dilakukan untuk meningkatkan fungsi fisiologi yang dapat memperbaiki funsi kardio-respirasi ( $V O 2 m a x)$. Namun demikian, latihan yang berlebihan dapat menyebabkan stres oksidatif yang dapat menimbulkan gangguan kesehatan. Penelitian ini bertujuan untuk mengkaji efek latihan terhadap peroksidasi lipid serum pada pemain sepak bola mahasiswa. Penelitian ini adalah penelitian pendahuluan dengan rancangan kasul bentuk tunggal dilakukan pada April 2014. Dua belas pemain sepak bola mahasiswa dari UGM dipilih dengan teknik purposive sampling sesuai kriteria inklusi dan eksklusi dilibatkan dalam penelitian. Setiap subjek menjalani latihan untuk ditetapkan $V \mathrm{O} 2$ max nya dengan uji yo-yo intermittent recovery. Kadar malondialdehid (MDA) plasma diukur dengan metode asam tiobarbiturat 30 menit setelah pengukuran $V \mathrm{O} 2 \mathrm{max}$. Uji korelasi Pearson digunakan untuk menganalisis hubungan antara $\mathrm{VO} 2 \mathrm{max}$ dan kadar MDA plasma. Rerata umur subjek adalah $19.25 \pm 1.06$ tahun. Subjek mempunyai status gizi normal (indeks masa tubuh $20.99 \pm 1.65$ ) dengan rerata berat badan $58.13 \pm 3.76 \mathrm{~kg}$ dan tinggi badan 166.20

\footnotetext{
*corresponding author : puspaningtyas.desty@gmail.com
} 
$\pm 3.40 \mathrm{~cm}$. Rerata skor $V O 2 \mathrm{max}$ adalah $49.56 \pm 0.61 \mathrm{~mL} / \mathrm{kg} / \mathrm{menit}$. Rerata kadar MDA plasma adalah $4.32 \pm 2.09 \mu \mathrm{mol} / \mathrm{L}$. Tidak ada korelasi nyata antara $V \mathrm{O} 2 \mathrm{max}$ dan kadar MDA plasma. Dapat disimpulkan, pelatihan tidak menyebabkan stress oksidatif yang merugikan pada pemaian sepak bola mahasiswa.

Keywords: soccer - exercise - VO2max - lipid peroxidation - malondialdehyde

\section{INTRODUCTION}

Physical exercise is beneficial to the body, particularly for physical and psychological health and social wellbeing. Additionally, physical exercise can delay the aging process. There is an increase in the sympathetic nerve response at the beginning of physical exercise. Next, the cardiovascular system adaptation is adjusted, resulting in an increase in cardiac rate, cardiac force, and arterial pressure. There is also an increase in metabolism, blood glucose concentrations, and glycolysis in the liver and muscles. Furthermore, the respiratory system adapts. These factors contribute to good athletic performance. ${ }^{1}$ For example, study conducted on a male athlete who did a solo ultra-endurance open-water swim showed that heart rate increased by $41.8 \%$ and salivary alpha-amylase (sAA) levels increased by $102.6 \%$ after athlete completed swim $78.1 \mathrm{~km}$ in $23 \mathrm{~h} 44 \mathrm{~min}$. It confirmed that the autonomic drives depend upon exercise efforts. Indeed, exercise by doing ultra-endurance swim differently influenced cardiac function by both adaptive autonomic and non-autonomic patterns. ${ }^{2}$ An additional study in seven healthy adult male sport-parachutists demonstrated that exercise done in the form of parachute jumping led to a strong response of salivary cortisol, $\alpha$-amylase, and heart rate. There was an increase of salivary cortisol and $\alpha$-amylase levels and heart rate at $12 \mathrm{~h}$ before jumping (basal) and within $60 \mathrm{~s}$ (jump). ${ }^{3}$
Soccer is a sport that requires strength and cardiorespiratory endurance, because the distances covered during a game range from 9,800 to $11,500 \mathrm{~m}^{4-5}$ Soccer is accompanied by strong and explosive activities, such as jogging, sprinting, jumping, tackling, and heading and kicking the ball., ${ }^{4} 6$ Therefore, exercise is important to increasing the cardiorespiratory response of soccer players. One study indicated that to significantly improve achievement, athletes must increase their performance, because performance is one of the primary determinants of a win. Athletes receive training and exercise to improve their performance. Not only do athletes receive training focused on techniques and tactics but also to improve physical fitness. ${ }^{4}$

Cardio-respiratory function ( $V \mathrm{O} 2 \mathrm{max})$ measurements can represent physical fitness. $V \mathrm{O} 2 \mathrm{max}$ is an upper limit measurement of the ability of the body to consume, distribute, and use oxygen. $V \mathrm{O} 2 \mathrm{max}$ is defined as the integrated physiological function of the lungs, heart, blood, and muscles. ${ }^{7}$ The average endurance score of soccer players belonging to Gelora Remaja Football Club, Division I Football of Football Association of Pasuruan District (Persekabas) illustrated by $\mathrm{VO}_{2} \max$ measurement using the multistage shuttle run test was $38.13 \mathrm{~mL} / \mathrm{kg} /$ minute. ${ }^{8}$ The average endurance score of soccer players belonging to Football Association of Kudus District, Central Java, Indonesia measured by VO2max using the cooper test was $50 \mathrm{~mL} / \mathrm{kg} /$ minute. $^{9}$ 
Study conducted by Luhtanen et al. ${ }^{10}$ reported that the cardiorespiratory function of young soccer player measured by $\mathrm{VO} 2$ max test on a treadmill starting at a speed of $9 \mathrm{~km} / \mathrm{h}$ and increasing speed by $1 \mathrm{~km} / \mathrm{h}$ after every three minutes was $53.5 \mathrm{~mL} / \mathrm{kg} / \mathrm{min}$. Another study reported that mean values for an oxygen consumption of non-elite university-level Gaelic footballers ranged from 54.77 to 65.31 $\mathrm{mL} / \mathrm{kg} / \mathrm{min}$ for soloing with the ball and 52 to $63.63 \mathrm{~mL} / \mathrm{kg} /$ minute for running without the ball. ${ }^{11}$ Hence, training and exercise are needed to increase the cardiorespiratory response $(V \mathrm{O} 2 \mathrm{max})$ from soccer players. Previous study demonstrated that weekly $30 \mathrm{~min}$ session of intermittent high-intensity drills could increase physical performance of highlevel soccer players in the competitive season measured by $V \mathrm{O} 2 \mathrm{max}$ using an incremental treadmill test. The $V \mathrm{O} 2 \mathrm{max}$ after training and exercise period $(62.2 \mathrm{~mL} / \mathrm{kg} / \mathrm{min})$ was higher than $V O 2 m a x$ before training and exercise period $(59 \mathrm{~mL} / \mathrm{kg} / \mathrm{min}){ }^{12}$

Although exercise confers numerous benefits, rigorous physical exercise can cause oxidative stress. ${ }^{1,13-15}$ Oxidative stress is a condition in which there is an imbalance between free radicals and antioxidants. ${ }^{16}$ Study conducted on nine futsal athletes showed that significantly $15 \mathrm{~min}$ after exercise there was an increasing of MDA levels-an indicator of oxidative stress. ${ }^{1}$ Study conducted by Souza et al. ${ }^{14}$ reported that exercise with treadmill running increased plasmatic MDA concentration during and after its performance. Another study in 24 physical education students indicated that concentration of MDA as oxidative stress indices significantly increased at immediately and $24 \mathrm{~h}$ after aerobic exercise. ${ }^{15}$ One study determined that aerobic exercise with moderate intensity caused an increase in oxygen consumption that triggered free radical formation by mitochondria. Free radical formation can harm cells, proteins, DNA, and other cellular components through the oxidation process. ${ }^{17}$

Exercise can produce an imbalance between reactive oxygen species (ROS) and antioxidants, commonly known as oxidative stress. Physical exercise increases free radical production through multiple pathways. Of the oxygen used in the mitochondria, $2-5 \%$ produces free radicals. Increased oxidative phosphorylation results in increased free radical production. If the rise in free radicals is greater than the ability of the body to neutralize it, the free radicals will attack cell components and particularly body fat. An attack on body fat is commonly known as lipid peroxidation, which can further increase free radicals. ${ }^{16}$

A frequently used indicator of lipid peroxidation is MDA. ${ }^{13,16}$ Serum MDA levels can significantly increase under high oxidative stress conditions. ${ }^{16}$ Thus, it is critical to better understand the correlation between exercise, as assessed by $V \mathrm{O} 2 \mathrm{max}$ measurements, and MDA levels. Several studies investigating professional athletes have demonstrated that rigorous physical exercise can cause oxidative stress, although these findings are controversial. In this study, we assessed the effect of exercise, using yo-yo intermittent recovery test, on serum lipid peroxidation levels in student soccer players.

\section{MATERIALS AND METHODS}

\section{Subjects}

This study was pre-experimental study with a one-shot case design or a one-group post only design. This study examined the effect of exercise, as assessed by $V \mathrm{O} 2 \mathrm{max}$ measurements, on plasma MDA levels in student soccer players conducted in April 2014. Twelve student soccer players from 
UGM who lived in Yogyakarta Special Region and chosen by purposive sampling as well as met the inclusion and exclusion criteria were involved in the study. The inclusion criteria for subjects were willingness to participate in the study, male, age $\geq 18$ years, non-smokers, not taking supplements during the study, and having lived in the study area for at least 6 months. Exclusion criteria included injury, fracture, or treatment during the study.

\section{Protocol of the study}

Prior to the study subjects received an explanation concerning the background, objectives and benefit of the study. Subjects were given an informed consent to be signed. Characteristics of subjects including age, weight, height, body mass index (BMI), educational level, and position on the team were recorded. Each subject then received training in the form of $V \mathrm{O} 2 \mathrm{max}$ measurements at the Stadium of Universitas Negeri Yogyakarta (UNY) using the yo-yo intermittent recovery test followed by exercise until the subject reached $80 \%$ of their maximum heart rate. In yo-yo intermittent recovery test, subjects must start on or behind the line, and began running $20 \mathrm{~m}$ when instructed by the recorder. Then, subject turned and returned to the starting point when signaled by the recorded beep. A warning was given when the subject did not complete a successful out and back shuttle in the allocated time. Subject was removed the next time when subject did not complete a successful shuttle. The type of exercise performed by the subjects was anaerobic endurance with fartlek training, which included walking, jogging, and sprinting. Subjects then cooled down for five min. The equation used to calculate the $V \mathrm{O} 2 \mathrm{max} .{ }^{18}$ $V \mathrm{O} 2 \mathrm{max}(\mathrm{mL} / \mathrm{min} / \mathrm{kg})=$ [yо-уо intermittent recovery test distance $(\mathrm{m}) \times 0.0136]+45.3$.
Thirty min after $V \mathrm{O} 2$ max measurements followed by exercise (anaerobic endurance with fartlek type), blood samples were collected and plasma MDA levels were measure spectrophotometrically using the thiobarbituric acid method at Laboratory of Biochemistry, Faculty of Medicine, Universitas Gadjah Mada, Yogyakarta. The day prior to analysis, study subjects received instructions through a short messages service. Specifically, the subjects were instructed not to do heavy activities, such as running or other exercise, to sleep at least $6-8 \mathrm{~h}$, and to not drink caffeinated drinks, alcohol, or vitaminmineral drinks. A 24-h food recall form, food record form, and questionnaire of sleep quality index were used to correct for the subject's condition and the subject's restraint. The protocol of the study has been approved by the Medical and Health Research Ethics Committee (MHREC), Faculty of Medicine, Universitas Gadjah Mada, Yogyakarta (KE/ FK/257/EC).

\section{Statistical analysis}

Data were analyzed using the StataIC 12 statistical program, and the Shapiro-Wilk test was used to analyze data distribution. Pearson correlation coefficient was used to analyze the correlation between exercise (VO2max) and plasma MDA levels as well as between subject's restraint focused on food consumption (energy, fat, and carbohydrate intake) and plasma MDA levels. Spearman correlation was used to analyze the correlation between protein, vitamin A, carotene, vitamin $\mathrm{E}$, and vitamin $\mathrm{C}$ intake and plasma MDA levels. A p-value $\leq 0.05$ was considered significant. 


\section{RESULTS}

The characteristics of subjects are presented in TABLE 1, whereas the VO2max scores and plasma MDA levels are presented in TABLE 2.

TABLE 1. Characteristics of subjects

\begin{tabular}{lc}
\hline \multicolumn{1}{c}{ Characteristics } & Mean $\pm \mathbf{S D} / \mathbf{N}(\mathbf{\%})$ \\
\hline Age (years) & $19.25 \pm 1.06$ \\
Weight $(\mathrm{kg})$ & $58.13 \pm 3.76$ \\
Height $(\mathrm{cm})$ & $166.52 \pm 3.40$ \\
BMI $\left(\mathrm{kg} / \mathrm{m}^{2}\right)$ & $20.99 \pm 1.65$ \\
Educational level & \\
Diploma degree & $5(41.67 \%)$ \\
Bachelor degree & $7(58.33 \%)$ \\
Position on the team & \\
Backs & $6(50 \%)$ \\
Midfielders & $5(41.67 \%)$ \\
Goal Keeper & $1(8.33 \%)$ \\
\hline
\end{tabular}

The backs and the midfielders showed comparable VO2max scores and plasma MDA levels, while the goalkeeper showed the lowest $V \mathrm{O} 2 \mathrm{max}$ score and plasma MDA level (TABLE 2). Moreover, the mean VO2max score was $49.56 \mathrm{~mL} / \mathrm{kg} / \mathrm{min}$, and the mean plsma MDA level was $4.32 \mu \mathrm{mol} / \mathrm{L}$. No significant correlation between $\mathrm{VO} 2 \mathrm{max}$ and plasma MDA levels was observed $(p=0.7717)$ (TABLE 2).

Other variables can also affect plasma MDA levels in student soccer players. Based on the subject questionnaires, seven subjects performed strenuous exercise, four subjects consumed caffeinated drinks, one subject consumed alcoholic drinks, and three subjects consumed supplements the day prior to the study. Additionally, four subjects did not sleep at least 6-8 hours. The $24-\mathrm{h}$ food recall and

TABLE 2. VO2max and plasma MDA levels (mean $\pm \mathrm{SD}$ ) by team position and its correlation

\begin{tabular}{llcccc}
\hline $\begin{array}{c}\text { Team } \\
\text { position }\end{array}$ & N (\%) & $\begin{array}{c}V \text { O2max } \\
(\mathbf{m L} / \mathbf{k g} / \mathbf{m i n})\end{array}$ & $\begin{array}{c}\text { MDA } \\
(\boldsymbol{\mu m o l} / \mathbf{L})\end{array}$ & Correlation & $\mathbf{p}^{*}$ \\
\hline Backs & $6(50 \%)$ & $49.83 \pm 0.44$ & $4.50 \pm 1.93$ & -0.0939 & 0.7717 \\
Midfielders & $5(41.67 \%)$ & $49.43 \pm 0.62$ & $4.60 \pm 2.37$ & & \\
Goalkeeper & $1(8.33 \%)$ & $48.56 \pm 0.00$ & $1.77 \pm 0.00$ & & \\
\hline Total & $12(100 \%)$ & $49.56 \pm 0.61$ & $4.32 \pm 2.09$ & & \\
\hline
\end{tabular}

VO2max: Cardio-respiratory function; MDA:Malondialdehyde; *Pearson correlation

food record forms were used to correct for food and drink consumption one day prior to the study. Statistical analysis of subject restraint demonstrated that there was no correlation between food consumption and plasma MDA levels (TABLE 3). 
TABLE 3. The subject restraint

\begin{tabular}{|c|c|c|c|}
\hline Subject restraint & $\mathbf{N}(\%)$ & $\begin{array}{c}\text { MDA } \\
(\text { mean } \pm \mathrm{SD} \mu \mathrm{mol} / \mathrm{L})\end{array}$ & $\mathbf{p}$ \\
\hline \multicolumn{4}{|l|}{ Physical activity } \\
\hline Active & $7(58.33 \%)$ & $4.15 \pm 2.11$ & 0.769 \\
\hline Non-active & $5(41.67 \%)$ & $4.54 \pm 2.29$ & \\
\hline \multicolumn{4}{|c|}{ Caffeinated drink consumption } \\
\hline Yes & $4(33.33 \%)$ & $3.11 \pm 1.17$ & 0.167 \\
\hline No & $8(66.67 \%)$ & $4.92 \pm 2.25$ & \\
\hline \multicolumn{4}{|l|}{ Alcohol consumption } \\
\hline Yes & $1(8.33 \%)$ & $7 \pm 0.00$ & 0.192 \\
\hline No & $11(91.67 \%)$ & $4.07 \pm 2.01$ & \\
\hline \multicolumn{4}{|l|}{ Supplement consumption } \\
\hline Yes & $3(25 \%)$ & $3.98 \pm 2.99$ & 0.763 \\
\hline No & $9(75 \%)$ & $4.43 \pm 1.93$ & \\
\hline \multicolumn{4}{|l|}{ Sleep quality } \\
\hline Good & $1(8.33 \%)$ & $7.42 \pm 0.00$ & 0.111 \\
\hline Poor & $11(91.67 \%)$ & $4.03 \pm 1.94$ & \\
\hline \multicolumn{4}{|l|}{ Food consumption } \\
\hline Energy (kcal) & $2197.97 \pm 453.96^{\mathrm{a}}$ & $4.32 \pm 2.09$ & $0.326^{\mathrm{c}}$ \\
\hline Protein $(g)$ & $45.55(36.2-85.9)^{b}$ & & $0.430^{\mathrm{d}}$ \\
\hline Fat $(\mathrm{g})$ & $53.43 \pm 17.78^{\mathrm{a}}$ & & $0.568^{\mathrm{c}}$ \\
\hline Carbohydrate (g) & $380.63 \pm 88.98^{\mathrm{a}}$ & & $0.270^{\mathrm{c}}$ \\
\hline Vitamin $\mathrm{A}(\mu \mathrm{g})$ & $31.5(0-210)^{b}$ & & $0.197^{\mathrm{d}}$ \\
\hline Carotene (mg) & $763.75(62.4-28680)^{\mathrm{b}}$ & & $0.713^{\mathrm{d}}$ \\
\hline Vitamin E (mg) & $0(0-0.9)^{\mathrm{b}}$ & & $0.187^{\mathrm{d}}$ \\
\hline Vitamin C (mg) & $21.15(0-643)^{b}$ & & $0.527^{\mathrm{d}}$ \\
\hline
\end{tabular}

MDA: malondialdehyde; ${ }^{\mathrm{a}}$ mean $\pm \mathrm{SD}$; ${ }^{\mathrm{b}}$ median (min-max); ${ }^{\mathrm{c}}$ Pearson correlation; ${ }^{\mathrm{d}}$ Spearman correlation

\section{DISCUSSION}

We demonstrated that the backs and the midfielders had comparable $V O 2$ max scores and MDA levels, while the goalkeeper had the lowest $V \mathrm{O} 2 \mathrm{max}$ score and MDA level (TABLE 2). Previous studies reported the little difference between positions in the distances covered by soccer players. However, it was reported that fullbacks sprinted more than twice as much as central-defenders (2.5 times longer), while midfielders and attackers sprinted significantly more than centraldefenders (1.6-1.7 times longer). Moreover, fullbacks and attackers sprinted significantly longer than central-backs and midfielders. ${ }^{4}$
Different distances covered by athletes result in different $V \mathrm{O} 2 \mathrm{max}$ scores and plasma MDA levels. This study investigated $\mathrm{VO} 2$ max score and plasma MDA level differences in the backs as a group; however, an investigation of more specific positions, such as full back or centralback, may reveal additional differences.

No significant correlation between VO2max scores and plasma MDA levels was observed in this study (TABLE 3). This results differed from those of a previous study that reported the increase of plasma MDA levels 15 min after exercise in nine futsal athletes significantly. ${ }^{1}$ Previous study reported that exercise with treadmill running 
increase plasma MDA levels during and after its performance. ${ }^{14}$ Another study conducted in 24 physical education students reported that plasma MDA levels increase immediately and $24 \mathrm{~h}$ after aerobic exercise. ${ }^{15}$ Athletes receive training not only to improve performance of technical skills, tactical skills, and athletic experience, but also to improve physiological functions, psychological functions, and social wellbeing. ${ }^{6,19}$ Moreover, physical exercise can delay the aging process. ${ }^{1}$

Although exercise increases athletic performance, rigorous physical exercise can cause oxidative stress, which is associated with fatigue and cell damage. ${ }^{1,13-15,20}$ Oxidative stress is a condition in which there is an imbalance between free radicals and antioxidants. ${ }^{16}$ There is an alteration in heart function and blood volume during aerobic exercise, which results in higher oxygen consumption. Exercise causes blood capillary proliferation and increased mitochondrial enzymes, alternating muscle metabolism. This results in increased lipid peroxidation. ${ }^{6}$

One study demonstrated that aerobic exercise with moderate intensity leads to increased oxygen consumption, impacting free radical formation by the mitochondria. Free radical formation can endanger lipid cells, proteins, DNA, and other cells through the oxidation process. ${ }^{17}$ During physical exercise, oxygen plays an important role. It is necessary during physical exercise, however it can also be a dangerous substance due to it can increase oxidative stress. Increased oxygen volume will increase skeletal muscle metabolism, which can increase the production of ROS, a free radical with negative consequences. Additionally, NADPH oxidase activity, PLA2-dependent processes, xanthine oxidase activity, and phagocyte cells can increase ROS production. ${ }^{21}$
Malondihaldehyde is an indirect measurement of free radical activity. ${ }^{16}$ Some studies reported that oxidative stress from lipid peroxidation can be measured by MDA levels. ${ }^{1,14}$ Malondihaldehyde $\left(\mathrm{C}_{3} \mathrm{H}_{4} \mathrm{O}_{2}\right)$ is a compound with a three carbon chain and results from lipid oxidation, particularly from arachidonate, eicosapentaenoate, and docosahexaenoate fatty acids. ${ }^{14}$ Several studies have used MDA as an indicator of oxidative stress caused by exercise. When a free radical is formed, it can attack polyunsaturated fatty acids in the cell membrane, causing the formation of other chemical reactions, commonly called lipid peroxidation. The fatty acids are then broken down and produce carbon gases (ethane or pentane) as well as aldehyde formation. ${ }^{16}$

This results differed from previous study indicating that excessive physical activity can increase oxidative stress, characterized by elevated plasma MDA levels. There are several possible explanations as to why this study differed from others. Under high oxidative stress conditions, plasma MDA levels significantly increase. When oxidative stress is resolved, plasma MDA levels normally decrease. ${ }^{14}$ Athletes may be able to better compensate for the free radical elevation, which can cause lipid peroxidation and consequently increased plasma MDA levels.

Several factors contribute to overcoming oxidative stress. Subjects with increased physical activity displayed lower MDA levels than subjects with non-active physical activity, although it was not statistically significant (TABLE 4). Metin et al. ${ }^{13}$ suggested that regular exercise may be beneficial in cases of oxidative stress by reducing lipid peroxidation and increasing the activity of the antioxidant enzyme superoxide dismutase. Another 
variable that may contribute to plasma MDA levels was alcohol consumption. A previous study by Deshpande et al..$^{22}$ demonstrated a correlation between plasma MDA levels and alcohol consumption. In this study, a subject who consumed alcohol displayed higher plasma MDA levels than those of subjects who did not. Additionally, subjects taking vitamin supplements displayed lower plasma MDA levels than those of subjects who did not. Based on subject interviews, the most common supplement consumed was vitamin C. Free radicals, as part of the oxidative stress process, can be neutralized by the antioxidant defense system. The antioxidant defense system consists of enzymatic antioxidants, such as catalase, superoxide dismutase, glutathione peroxidase, and non-enzymatic antioxidants, including vitamin $\mathrm{A}, \mathrm{E}, \mathrm{C}$, glutathione, ubiquinone, and flavonoids. ${ }^{16}$ Antioxidant supplementation can neutralize ROS and reactive nitrogen species and reduce the risk of muscle damage. Supplementation with $1000 \mathrm{mg}$ vitamin $\mathrm{C}$ and $300 \mathrm{mg}$ $\alpha$-tocopherol acetate can prevent exerciseinduced lipid peroxidation. ${ }^{23}$

Vitamin $\mathrm{C}$ serves as an antioxidant by reacting with free radicals, thus reducing the ability of free radicals to attack polyunsaturated fatty acids and improving plasma MDA levels. One study demonstrated that vitamin C supplementation prevented endurance exercise-induced lipid peroxidation. ${ }^{24}$ Additionally, vitamin C can overcome ROS, including superoxide or hydroxyl radicals. ${ }^{25}$ Supplementation with vitamin $\mathrm{C}$ and vitamin $\mathrm{E}$ helps to reduce markers of exercise-induced muscle damage. This was illustrated by the significant reduction in oxidative stress markers (creatine kinase and malondialdehyde) in a group receiving $250 \mathrm{mg}$ of vitamin $\mathrm{C}$ or both vitamin $\mathrm{C}$ and vitamin E supplementation. ${ }^{26}$
Vitamin E also plays a role as an antioxidant. Vitamin E supplementation for two weeks can significantly decrease MDA levels before and after an ergometric test, which measures performance. ${ }^{27}$ A study investigating $\beta$ carotene, vitamin $\mathrm{E}, \mathrm{A}, \mathrm{C}$, zinc, and selenium supplementation demonstrated that serum MDA levels were remarkably reduced after two weeks of supplementation. Furthermore, hemoglobin levels, packed cell volume (PCV), and red blood cells (RBC) in Indian athletes were also improved. ${ }^{28}$

One weakness of this study is that we did not measure other variables that can be used as oxidative stress indicators, such as lipid hydroperoxide, creatine kinase, superoxide radicals, and other radicals. Additionally, this study did not measure the antioxidant capacity of the body, including measurements of catalase, superoxide dismutase, and glutathione peroxidase levels. This study was pre-experimental with a one-shot case study design or a one-group post only design. Thus, the researcher did not know the differences before and after exercise or training. Another weakness is that the subjects only received restraint instructions through a short message service. The results should be validated following subject quarantine prior to the study to control the restraints.

\section{CONCLUSION}

There is no correlation between $\mathrm{VO} 2 \mathrm{max}$ scores and plasma MDA levels indicating that training or exercise do not negatively impact oxidative stress conditions in student soccer players following $V \mathrm{O} 2$ max measurement using the yo-yo intermittent recovery test. Further research will be performed to investigate other variables that can be used as oxidative stress indicators, such as lipid hydroperoxide, creatine kinase, superoxide radicals, and 
other radicals. In addition, further research is also needed to investigate the antioxidant capacity of the body, including measurements of catalase, superoxide dismutase, and glutathione peroxidase levels.

\section{ACKNOWLEDGMENTS}

The authors would like to thank Mr. Komarudin, M.A., Mr. Geovany Akbar, and Mr. Benny Criya Permana for their valuable assistances during data collection. The authors would also like to thank the athletes who participated in this study.

\section{REFERENCES}

1. Valado A, Pereira L, Tavares PC, Ribeiro CF. Effect of the intense anaerobic exercise on nitric oxide and malondialdehyde in studies of oxidative stress. Int J Biol Biomed Engin 2007;1(1):32-6.

2. Valenzano A, Moscatelli F, Triggiani AI, Capranica L, De Ioannon G, Piacentini MF, et al. Heart rate changes after ultra-endurance swim from Italy to Albania: a case report. Int J Sports Physiol Perform 2015; 11(3):407-9. http://dx.doi.org/10.1123/ijspp.2015-0035

3. Giovani M, Valenzano A, Moscatelli F, Triggiani AI, Capranica L, Messina A, et al. Effects of emotional stress on neuroendocrine and autonomic functions in skydiving. $\mathrm{J}$ Psychiatry 2015; 18(4):1-7. http://dx.doi.org/10.4172/Psychiatry. 1000280

4. Stolen T, Chamari K, Castagna C, Wisloff U. Physiology of soccer: an update. Sports Med 2005; 35(6):501-36.

http://dx.doi.org/10.2165/00007256200535060-00004

5. Irawan MA. Cairan, karbohidrat dan performa sepak bola. Sports Science Brief 2007; 01(05).

6. Bangsbo Jens. Physiology of training. In: Thomas Reilly (ed) Science and Soccer. UK: Spon Press Taylor \& Francis Group. 2003.
7. Reilly T. Fitness assessment. In: Thomas Reilly (ed) Science and Soccer. UK: Spon Press Taylor \& Francis Group. 2003

8. Penggalih MHST, Huriyati E. Gaya hidup, status gizi dan stamina atlet pada sebuah klub sepak bola. Berita Kedokteran Masyarakat 2007; 23(4):192-9.

9. Alfiyana L, Murbawani EA. Pengaruh pemberian air kelapa terhadap kebugaran atlet sepak bola. J Nutr Coll 2012; 1(1):336-49.

10. Luhtanen P. Nummela A, Lipponen K. Physical loading, stress, and recovery in a youth soccer tournament. In: Thomas Reilly and Feza Korkusuz (ed) Science and Football VI, The Proceedings of the Sixth World Congress on Science and Football. New York: Routledge. 2009.

11. Hulton A, Ford T, Reilly T. The energy cost of soloing a gaelic football. In: Thomas Reilly and Feza Korkusuz (ed) Science and Football VI, The Proceedings of the Sixth World Congress on Science and Football. New York: Routledge. 2009.

12. Jensen, Jack Majgaard, Morten Bredsgaard Randers, Peter Krustrup, Jens Bangsbo. Intermittent high-intensity drills improve inseasonal performance of elite soccer players. In: Thomas Reilly and Feza Korkusuz (ed) Science and Football VI, The Proceedings of the Sixth World Congress on Science and Football. New York: Routledge. 2009.

13. Metin G, Atureken P, Alturfan AA, Gulyasar T, Kaya M, Gumustas MK. Lipid peroxidation, erythrocyte superoxide-dismutase activity and trace metals in young male fotballers. Yonsei Med J 2003; 44(6):979-86. http://dx.doi.org/10.3349/ ymj.2003.44.6.979

14. de Souza TP Jr, de Oliveira PR, Pereira B. Physical exercise and oxidative stress effect of intense physical exercise on the urinary chemiluminescence and plasmatic malondialdehyde. Rev Bras Med Esporte 12005; 1(1):91-6. 
http://dx.doi.org/

$10.1590 / \mathrm{S} 1517-$ 86922005000100010

15. Atashak S, Sarafi H. Plasma malondialdehyde response to aerobic exercise after T. polium supplementation. Eur J Exp Biol 2013; 3(2):499-502.

16. Urso ML, Clarkson PM. Oxidative stress, exercise, and antioxidant supplementation. Toxicology 2003; 189(1-2):41-54.

http://dx.doi.org/10.1016/S0300483X(03)00151-3

17. Victor KL, McArdle WD, Katch FL. Essentials of exercise physiology, $4^{\text {th }} \mathrm{Ed}$. China: Lippincott Williams \& Wilkins. 2011.

18. Bangsbo J, Iaia FM, Krustrup P. The YoYo intermittent recovery test a useful tool for evaluation of physical performance in intermittent sports. Sports Med 2008; 38(1):37-51.

http://dx.doi.org/10.2165/00007256200838010-00004

19. William Clyde. Metabolic aspects of exercise. In: Reilly T, Secher N, Snell P, Williams C. (ed) Physiology of Sports. UK: Spon Press. 2005.

20. Eroglu Y, Daglioglu O. The effect of submaximal exercise on oxidant and antioxidant mechanisms in judokas and sedentary. Int J Sport Std 2013; 3(5):480-6.

21. Powers SK, Nelson WB, Hudson MB. Exercise-induced oxidative stress in humans: cause and consequences. Free Radic Biol Med 2011; 51(5):942-50.

h t tp://dx.doi.org/10.1016/j. freeradbiomed.2010.12.009

22. Deshpande N, Kandi S, Kumar PVB, Ramana $\mathrm{KV}$, Muddeshwar M. Effect of alcohol consumption on oxidative stress markers and its role in the pathogenesis and progression of liver cirrhosis. Am J Med Biol Res 2013; 1(4):99-102. http://dx.doi.org/10.12691/ajmbr-1-4-3

23. Mastaloudis A, Morrow JD, Hopkins DW, Devaraj S, Traber MG. Antioxidant supplementation prevents exercise-induced lipid peroxidation, but not inflammation, in ultramarathon runners. Free Radic Biol Med 2004; 36(10):1329-41.

h t t p : / / d . d o i.org/10.1016/j. freeradbiomed.2004.02.069

24. Nakhostin-Roohi B, Babaei P, RahmaniaNia F, Bohlooli S. Effect of vitamin C supplementation on lipid peroxidation, muscle damage and inflammation after 30min exercise at $75 \%$ Vo2max. J Sports Med Phys Fitness 2008; 48(2):217-24.

25. Gallagher, Margie Lee. The nutrients and their metabolism. In: Krause's Food \& Nutrition Therapy Edition 12. Canada: Elsevier. 2008.

26. Taghiyar M, Darvishi L, Askari G, Feizi A, Hariri M, Mashhadi NS, et al. The effect of vitamin $\mathrm{C}$ and $\mathrm{E}$ supplementation on muscle damage and oxidative stress in female athletes: a clinical trial. Int J Prev Med 2013; 4(Suppl 1):16-23.

27. Roshan VD, Najafabadi EM. The effect of short-term vitamin E supplementation on some indexes of sport performance and lipid per-oxidation in healthy men. World J Sport Sci 2009; 2(2):75-81.

28. Kelkar G, Subhadra K, Chengappa RK. Effect of antioxidant supplementation on hematological parameters, oxidative stress and performance of Indian athletes. J Hum Ecol 2008; 24(3):209-13. http://dx.doi.org/10.1080/09709274.2008.11 906116 